\title{
MEMBANGUN KESADARAN DEMOKRASI MELALUI PENDEKATAN KONTEKSTUAL PADA PEMBELAJARAN PENDIDIKAN KEWARGANEGARAAN
}

\author{
Bambang Yuniarto \\ Institut Agama Islam Negeri (IAIN) Syekh Nurjati Cirebon \\ bb_yunior@yahoo.co.id
}

\begin{abstract}
ABSTRAK
Tulisan ini merupakan kajian literatur yang membahas peningkatan kesadaran demokrasi warga negara dalam menyampaikan pendapat di muka umum melalui pendekatan kontekstual pada pembelajaran Pendidikan Kewarganegaraan. Kajian ini bertujuan untuk menggambarkan secara konseptual pendekatan pembelajaran kontekstual untuk meningkatkan kesadaran demokrasi warga negara dalam pelaksanaan kemerdekaan menyampaikan pendapat di muka umum. Metode kajian yang digunakan adalah analisis kepustakaan. Keseluruhan konsep, data dan informasi dihimpun dari berbagai sumber literatur seperti jurnal ilmiah, buku, laporan penelitian dan dokumen literatur lainnya; kemudian dianalisis dengan pendekatan kualitatif. Hasil kajian menunjukkan bahwa pendekatan pembelajaran kontekstual memiliki potensi sangat efektif untuk digunakan sebagai instrumen pendidikan kewarganegaraan dalam meningkatkan kesadaran warga Negara (siswa/mahasiswa) dalam pelaksanaan kemerdekaan berpendapat di muka umum.
\end{abstract}

Kata Kunci: Demokrasi, Pendekatan Kontekstual, Pendidikan Kewarganegaraan.

\begin{abstract}
This article is a literature study that discusses raising awareness of citizens' democracy in conveying public opinion through a contextual approach in the learning of citizenship education. This study aims to conceptually illustrate a contextual learning approach to improve the democratic awareness of citizens' independence in order to convey a public opinion. The method of study used is library analysis. Overall concepts, data and information are compiled from a variety of literary sources such as scientific journals, books, research reports and other literary documents; Then analyzed with a qualitative approach. Results showed that contextual learning approaches have a very effective potential to be used as a citizenship education instrument in raising awareness of citizens (students) in the conveying of independence argues in public.
\end{abstract}

Keywords: Democracy, contextual approach, citizenship education

Jurnal Edueksos Vol. IX, No. 1, Juni 2020

The journal of social and economics education 


\section{A. PENDAHULUAN}

Sejak orde reformasi berjalan hinggsa saat ini, kesadaran masyarakat akan nilai dan praktek demokrasi yang sejalan dengan hukum dinilai masih rendah. Situasi kehidupan bernegara yang paradox (undemocratic democracy), yakni di satu sisi kitasudah memiliki struktur (institusi) demokrasi, tetapi kesadaran berdemokrasinya masih rendah. Dalam analisis Azra (2007) bahwa masyarakat sekarang ini mengalami krisis sosial budaya dan politik yang menjelma dalam bentuk "disintegrasi”. Disintergrasi sosial-politik terjadi akibat euforia kebebasan yang kebablasan dan hilangnya kesabaran sosial (social temper) sehingga mudah melakukan tindakan kekerasan dan anarki dalam proses menyampaikan pendapat di muka umum. Dan dalam beberapa kasus, kegiatan demonstrasi massa seringkali berujung anarkhis, rusuh dan merusak sehingga melahirkan korban bentrok luka, bahkan meninggal, baik dari pihak pengunjuk rasa dan atau aparat keamanan.

Mencermati krisis yang digambarkan di atas, maka upaya membangun budaya dan kesadaran demokrasi menjadi hal yang serius dan mendesak. Diperlukan revolusi mental, yakni gerakan cepat dan radikat dalam membangun kesadaran moral masyarakat yang digerakkan secara simultan dan masif menuju bangsa yang beradab. Dan pendekatan strategis untuk gerakan itu salah satunya melalui proses pendidikan demokrasi. Pendidikan yang merujuk pada amanat konstitusiyakni UU No.20 Tahun 2003 yakni pendidikan demokrasi yang religius dan mencerdaskan. Tilaar (2002:7) juga menjelaskan bahwa pendidikan itu untuk mewujudkan masyarakat yang cerdas yakni suatu masyarakat Pancasilais, beriman dan bertakwa kepada Tuhan Yang Maha Esa, maju dan mandiri dan berwawasan budaya.

Pendidikan demokrasi ini penting dilakukan saat ini untuk meningkatkan kemelekan masyarakat dalam politik (political literacy). Literasi Politik (political literacy) merupakan pengetahuan dan pemahaman warga negara tentang proses politik dan isu-isu politik, suatu pengetahuan dan pemahaman yang memungkinkan setiap warga negara dapat secara efektif melaksanakan perannya sebagai warga negara.Dengan demikian seperti dikemukakan Heryanto dalam Bakti (2012:109), literasi politik bukanlah semata konsep normatif, melainkan perpaduan antara 
pengetahuan, skill dan sikap politik. Menurut Karim dkk, (2015:6) Masyarakat yang rendah pemahamannya terhadap konsep dan prosedural politik (political illiteracy) terkait hak menyampaikan pendapat di muka umum,secara sosio-politik bisa memunculkan: (1) rentan terhadap propaganda politik yang dilakukan oleh kelompok-kelompok kepentingan tertentu. Kedua, dapat melahirkan perilaku politik yang merusak (defecting) seperti anarkhis dalam unjuk rasa. Ketiga, tanpa literasi politik yang cukup mengenai praktik daily governing dan policy making, potensial dapat meningkatkan resiko menjauhnya politik dari kepentingan publik.

Pendidikan demokrasi adalah sub-bagian pendidikan kewarganegaraan di persekolahan (school civics). Terkait konteks ini menurut Winataputra (2008:9) bahwa pendidikan kewarganegaraan di persekolahan (school civics) memiliki peran penting dalam mewujudkan budaya demokratis. Dalam konteks inilah penulis menawarkan penerapan konsep pembelajaran kontekstual (contextual teahing and learning) sebagai instrumen pembelajaran untuk meningkatkan literasi politik (melek politik) warga negara agar dapat memberikan dampak positif dan konstruktif terhadap pengetahuan-pengetahuan konsep, aturan hukum dan prosedural menyampaikan pendapat di muka umum.

Berdasarkan urgensi masalah yang diuraikan di atas, maka fokus kajian ini dapat dirumuskan dalam dua pertanyaan yakni: (1) Bagaimana urgensi peningkatan kesadaran demokrasibagi siswa/mahasiswa dalam menyampaikan pendapat di muka umum (2) Bagaimana pendekatan pembelajaran kontekstual (contextual teaching and learning) yang diimplementasikan pada pembelajaran Pendidikan Kewarganegaraan (PKn) di persekolahan untuk meningkatkan kesadaran demokrasi masyarakat. Kajian ini bertujuan untuk: (1) memahami dan mendeskripsikan urgensi kesadaran demokrasidalam kegiatan berpendapat di muka umum (2) memahami dan mendeskripsikan pembelajaran kontekstual sebagai pendekatan pembelajaran Pendidikan Kewarganegaraan di persekolahan dalam meningkatkan kesadaran demokrasi terkait berdemonstrasi.

\section{B. METODE PENELITIAN}

Kajian ini menggunakan pendekatan kualitatif dengan metode analisisnya adalah studi kepustakaan. Data, fakta dan informasi dikumpulkan dari berbagai 
sumber bacaan seperti buku, jurnal, laporan penelitian dan dokumen literatur lainnya, kemudian dianalisis secara kualitatif. Penelitian dengan pendekatan kualitatif ini adalah proses penelitian untuk memahami dan mendeskripsikan masalah-masalah sosial, dalam hal ini adalah kesadaran demokrasi warga negara terkait menyampaikan pendapat di muka umum dengan mengimplementasikan pendekatan pembelajaran kontekstual dalam pembelajaran kewarganegaraan di persekolahan.

\section{HASIL DAN PEMBAHASAN}

\section{Kesadaran Demokrasidan Pendidikan Demokrasi}

Kesadaran ini adalah suatu potensi seseorang atau kelompok yang mencakup aspek pengetahuan, sikap dan perilaku terhadap demokrasi. Oleh karena itu, adanya kesadaran seseorang terhadap demokrasi tampak dari sikap dan tingkah lakunya, dan dalam diri seseorang memiliki tingkatan yang berbeda-beda. Seperti yang dikemukakan N.Y.Bull, yang dikutif Djahiri (1985:24) bahwa kesadaran itu ada yang bersifat "anomous" (kesadaran yang tidak jelas dasar dan orientasinya); "heteronomous" (kesadaran yang berlandaskan dasar/orientasi motivasi yang beraneka ragam dan berganti-ganti); sosionomous (kesadaran yang berorientasi pada kiprah umum); autonomous (kesadaran terbaik yang didasari oleh konsep atau landasan yang ada dalam diri sendiri). Dari hirarki itu, maka kesadaran autonomous yang diharapkan dapat terbentuk dalam praktek demokrasi. Namun tentu, kesadaran ini tidak terbentuk secara otomatis. Untuk mencapai tingkat kesadaran itu diperlukan proses belajar (pendidikan demokrasi) dan berbagai pengalaman baik formal maupun non-formal.

Pendidikan demokrasi bagi warga negara adalah hal penting, bukan saja di Negara berkembang tetapi juga di negara maju, seperti Amerika dll. Urgensi kepentingan ini menurut Azra (2001:13) adalah masih tingginya apatisme politik masyarakat dan kecenderungan ketidakmelekan warga mesyarakat terhadap cara kerja dan lembaga-lembaga demokrasi yang ada. Melalui pendidikan demokrasi yang baik memungkinkan setiap warga negara melakukan praktek kehidupan yang demokratis di masa mendatang. 
Pendidikan demokrasi ini substansinya merupakan sub-bagian pendidikan kewarganegaraan di persekolahan (school civics). Dalam hal ini Winata (2005:12; 2008:9) menyatakan bahwa pendidikan kewarganegaraan di persekolahan (school civics) memiliki peranan strategis dalam mewujudkan budaya kewarganegaraan demokratis. Pendidikan kewarganegaraan adalah salah satu modal utama dalam mewujudkan pola hidup bermasyarakat yang beradab dan berbudaya. Untuk tujuan itu, maka kurikulum dan proses pembelajaran perlu diupayakan agar lebih mengarah pada tujuan pembangunan karakter bangsa yang diwujudkan dalam bentuk pembelajaran pengetahuan kewarganegaraan (civic knowledge), perilaku kewarganegaraan (civic disposition), dan kemampuan kewarganegaraan (civic skills) yang dapat mendukung berkembangnya budaya kewarganegaraan (civic culture).

Berkaitan dengan hal di atas, Gandal \& Finn (1992:5-6) mengusulkan bahwa pendidikan demokrasi harus dikembangkan dalam dua pola model. Kesatu, model pendidikan demokrasi berbasis sekolah dalam konteks pendidikan formal. Pengembangan model ini dibelajarkan dalam bentuk kegiatan intra, ko dan ekstrakurikuler yang bernuansa demokratis. Kedua, pendidikan demokrasi dalam konteks kehidupan masyarakat. Kedua model pendidikan demokratis yang dikemukakan Gandal dan Finn di atas, harus didesain secara holistik, sistemik dan berkesinambungan dalam sistem pendidikan Nasional. Selanjutnya diciptakan interaksi dalam pembelajaran yang bermakna melalui iklim budaya di sekolah maupun di luar sekolah. Pembelajaran di dalam kelas menurut Winata, (2007:226) dikembangkan sebagai laboratorium demokrasi (democratic laboratory), sementara di demokrasi sekolah sebagai "micro cosmos of democracy", dan masyarakat luas sebagai "open global democracy". Dengan demikian, pelajar memahami dan melatih dirinya secara langsung dalam kehidupan demokrasi yang sebenarnya. Inilah makna yang oleh Winata dan Budimansyah (2007:219) disebut sebagai "learning democracy, throught/ in democracy and for democracy" (belajar demokrasi, melalui demokrasi dan untuk demokrasi).

Pendidikan demokrasi dapat dilakukan dalam proses pembelajaran di kelas. Ciptakan situasi pembelajaran yang memungkinkan pelajar dapat belajar dalam Jurnal Edueksos Vol. IX, No. 1, Juni 2020 
kelompok, mengajar temen sendiri membuat presentasi dan memimpin diskusi kelas. Guru pun dapat mendorong perilaku demokratis melalui pelibatan pelajar dalam mengajukan pertanyaan. Jika pelajar merasa takut dan tidak mau bertanya atau berpendapat, maka guru harus dapat memotivasi pelajar bertanya atau berpendapat dalam diskusi kelas. Pendidikan demokrasi di sekolah dapat dilaksanakan melalui kegiatan ekstra kurikuler di luar kelas. Ekstra kurikuler, seperti olahraga, teater, tari, ataupun eskul yang lainya, memberi kesempatan pelajar dalam bekerja sama menuju tujuan bersama, dan seringkali mengharuskan untuk memilih pemimpin dan membuat keputusan. Dalam semua kegiatan itu, nilai dan norma demokrasi dapat dipraktekan dan tidak hanya sekedar teori-teori yang dipelajari di ruang kelas.

\section{Pembelajaran Kontekstual dan Implementasinya}

Secara harfiah, Komalasari (2010: 54) Pembelajaran kontekstual (contextual teaching and learning) dapat dimaknai sebagai pembelajaran yang berhubungan dengan konteks tertentu. Pembelajaran kontekstual ini merupakan alternatif dari model pembelajaran konvensional atau tradisional. Suryanti dkk, (2008: 2) menyatakan di negara-negara maju pendekatan kontekstual ini sudah lama digunakan dalam proses-proses pembelajaran di kelas-kelas sekolah.

Para ahli pendidikan secara umum memiliki pandangan yang relatif sama dan sepakat mengenai pembelajaran kontekstual ini. Johnson (2011:64) mengemukakan bahwa pendekatan kontekstual adalah pembelajaran yang bertujuan membantu peserta didik menghubungkan makna di dalam materi ajar dengan konteks kehidupan keseharian, yakni keadaan pribadi, sosial, dan budaya mereka. Sementara itu, Suprijono (2009:79), melihatnya bahwa pendekatan pembelajaran kontekstual merupakan konsep yang membantu guru mengaitkan antara materi yang diajarkannya dengan situasi dunia nyata, dan mendorong peserta didik membuat hubungan antara pengetahuan yang dimilikinya dengan penerapannya dalam kehidupan mereka sebagai anggota keluarga dan masyarakat. Pendekatan pembelajaran kontekstual merupakan prosedur pendidikan yang bertujuan membantu peserta didik memahami makna bahan pelajaran yang mereka pelajari, 
dengan cara menghubungkannya dengan konteks kehidupan mereka sendiri dalam demokrasi sosial dan budaya masyarakat.

Pendekatan pembelajaran kontekstual didasari oleh beberapa teori berikut (Suryanti dkk,2008:2): (1) Konstruktivisme Berbasis Pengetahuan (KnowledgeBased Constructivism). Teori ini menekankan pentingnya mengembangkan kemampuan siswa membangun sendiri pengetahuan mereka melalui keterlibatan aktif dalam proses belajar mengajar; (2) Pembelajaran Berbasis Usaha/Teori Pertumbuhan Kecerdasan (Effort-Based Learning/Incremental Theory of Intellegence). Teori menekankan pentingnya upaya keras untuk mencapai tujuan belajar yang akan memotivasi seseorang untuk terlibat dalam kegiatan yang berkaitan dengan komitmen untuk belajar; (3) Sosialisasi (Socialization). Teori ini ini memandang, bahwa belajar merupakan proses sosial yang menentukan tujuan belajar,oleh karenanya faktor sosial dan budaya perlu diperhatikan selama perencanaan pengajaran; (4) Pembelajaran Situasi (Situated Learning). Teori ini menekankan bahwa pengetahuan dan pembelajaran harus dikondisikan dalam fisik tertentu dan dalam konteks sosial (masyarakat, rumah, dan lain sebagainya) dalam mencapai tujuan belajar; (5) Pembelajaran Distribusi (Distributed Learning). Teori ini menekankan bahwa manusia merupakan bagian terintegrasi dari proses pembelajaran, oleh karenanya harus berbagi pengetahuan dan tugas-tugas pada individu lain serta demokrasi sekitar.

Menurut Suryanti dkk, (2008) secara teoritik, para ahli menjelaskan bahwa pembelajaran kontekstual sedikitnya terdapat 7 (tujuh) komponen yang harus dilakukan. Ketujuh komponen itu adalah sbb : (1) Konstruktivisme, meliputi pengertian: a) membangun pengetahuan mereka sendiri dari pengalaman baru berdasarkan pada pengetahuan awal; dan b) pembelajaran harus dikemas menjadi proses "mengkonstruksi” bukan menerima pengetahuan; (2) Inquiry, meliputi pengertian: a) proses perpindahan dari pengamatan menjadi pemahaman; dan b) peserta didik belajar menggunakan keterampilan berfikir kritis; (3) Questioning, meliputi pengertian: a) kegiatan guru untuk mendorong, membimbing dan menilai kemampuan berfikir peserta didik; dan b) bagi peserta didik yang merupakan bagian penting dalam pembelajaran yang berbasis inquiry; (4) Learning Jurnal Edueksos Vol. IX, No. 1, Juni 2020 
Community, meliputi pengertian : a) sekelompok orang yang terikat dalam kegiatan belajar; b) bekerjasama dengan orang lain lebih baik dari pada belajar sendiri; c) tukar pengalaman; d) berbagi ide; (5) Modeling, meliputi pengertian: a) proses penampilan suatu contoh agar orang lain berfikir, bekerja dan belajar; b) mengerjakan apa yang guru inginkan agar peserta didik mengerjakannya; (6) Reflection, meliputi: a) cara berfikir tentang apa yang telah kita pelajari; b) mencatat apa yang yang telah dipelajari; dan c) membuat jurnal, karya seni, dan diskusi kelompok; dan (7) Authentic Assessment, meliputi pengertian: a) mengukur pengetahuan dan keterampilan peserta didik; b) penilaian produk (kinerja); dan c) tugas-tugas yang relevan dan kontekstual.

Sementara itu di dalam buku yang diterbitkan Depdiknas (2006: 11) dirumuskan beberapa karakteristik pendekatan kontekstual sebagai berikut: (a) kerjasama, (b) saling menunjang, (c) menyenangkan, (d) tidak membosankan, (e) belajar dengan gairah, (f) pembelajaran terintegrasi, (g) siswa aktif, (h) sharing dengan teman, (i) menggunakan berbagai sumber, (j) siswa kritis dan guru kreatif, (k) dinding kelas dan lorong-lorong penuh dengan hasil karya siswa, dan (1) laporan kepada orang tua bukan rapor, melainkan hasil karya siswa.

\section{Pembelajaran Pendidikan Kewarganegaraan di Persekolahan}

Pendidikan Kewarganegaraan merupakan salah satu mata pelajaran di persekolahandari pendidikan dasar, menengah hingga perguruan tinggi. Pada tingkat pendidikan dasar dan menengah, mata pelajaran ini dapat dikatakan sebagai satu-satunya pelajaran yang memuat secara khas mater-materi pembelajaran yang berhubungan langsung dengan isu-isu politik, kenegaraan dan pemerintahan, termasuk di dalamnya kajian mengenai ideologi, konstitusi, dan demokrasi.

Secara akademik, menurut Al Hakim dkk, (2012: 8) pendidikan kewarganegaraan adalah program pendidikan yang berfungsi untuk membina kesadaran warga negara dalam melaksanakan hak dan kewajibannya sesuai dengan jiwa dan nilai konstitusi yang berlaku (UUD 1945). Analisis tersebut secara substantif sama dengan rumusan yang terdapat di dalam lampiran Permendiknas Nomor 22 Tahun 2006 tentang Standar Isi untuk Satuan Pendidikan Dasar dan Menengah, bahwa Mata Pelajaran Pendidikan Kewarganegaraan merupakan mata 
pelajaran yang memfokuskan pada pembentukan warga negara yang memahami dan mampu melaksanakan hak-hak dan kewajibannya untuk menjadi warga negara yang cerdas, terampil, dan berkarakter yang diamanatkan oleh Pancasila dan UUD 1945.

Di dalam Permendiknas tersebut juga dirumuskan ruang lingkup mata pelajaran Pendidikan Kewarganegaraan untuk pendidikan dasar dan menengah, yang secara umum meliputi aspek-aspek sebagai berikut: (a) Persatuan dan Kesatuan Bangsa, meliputi hidup rukun dalam perbedaan, cinta demokrasi, kebanggaan sebagai bangsa Indonesia, sumpah pemuda, keutuhan negara kesatuan republik Indonesia, partisipasi dalam pembelaan negara, sikap positif terhadap megara Kesatuan Republik Indonesia, keterbukaan dan jaminan keadilan; (b) Norma, Hukum dan Peraturan, yang meliputi tertib dalam kehidupan keluarga, tata tertib di sekolah, norma yang berlaku di masyarakat, peraturan-peraturan daerah, norma-norma dalam kehidupan berbangsa dan bernegara, sistem hukum dan peradilan internasional; (c) Hak Asasi Manusia, meliputi hak dan kewajiban anak, hak dan kewajiban anggota masyarakat, instrument nasional dan internasional HAM, pemajuan, penghormatan dan perlindungan HAM; (d) Kebutuhan Warga Negara, meliputi hidup gotong royong, harga diri sebagai warga masyarakat, kebebasan berorganisasi, kebebasanmengeluarkan pendapat, menghargai keputusan bersama, prestasi diri, persamaan kedudukan warga negara; (e) Konstitusi Negara, meliputi proklamasi kemerdekaan dan konstitusi pertama, konstitusi-konstitusi yang pernah digunakan di Indonesia, hubungan dasar negara dengan konstitusikonstitusi yang pernah digunakan di Indonesia, hubungan dasar negara dengan konstitusi; (f) Kekuasaan dan Politik, meliputi pemerintahan desa dan kecamatan, pemerintahan daerah dan otonomi pemerintah pusat, demokrasi dan sistem politik, budaya politik, budaya demokrasi menuju masyarakat madani, sistem pemerintahan, pers dalam masyarakat demokrasi; (g) Pancasila, meliputi kedudukan pancasila sebagai dasar negara dan ideologi negara, proses perumusan pancasila sebagai dasar negara, pengamalan nilai-nilai pancasila dalam kehidupan sehari-hari, pancasila sebagai ideologi terbuka; dan (h) Globalisasi, meliputi globalisasi di demokrasinya, politik luar negeri Indonesia di era globalisasi, dampak 
globalisasi, hubungan internasionl dan organisasi internasional, dan mengevaluasi globalisasi.

\section{Implementasi pendekatan kontekstual dalam pembelajaran PKn}

Di bawah ini disampaikan implementasi pembelajaran kontekstual dalam mata pelajaran/mata kuliah Pendidikan Kewarganegaraan untuk meningkatkan kesadaran warga Negara dalam melestarikan demokrasi, yakni :

\section{Constructivism (Konstruktivisme).}

Kontrukstivisme menurut Suryanti dkk, (2008:7) merupakan landasan berpikir pendekatan kontekstual, dimana pengetahuan dibangun oleh manusia sedikit demi sedikit, yang hasilnya diperkuat melalui konteks yang terbatas (sempit) dan tidak tiba-tiba .Gagasan konstruktivisme sebagai komponen pertama pembelajaran kontekstual lebih menekankan pada aktivitas siswa dalam menemukan dan membangun (mengkonstruksi) pemahaman sendiri daripada kemampuan menghafal teori-teori yang ada dalam buku pelajaran. Karenanya siswa/mahasiswa perlu dikondisikan untuk terbiasa mengidentifikasi masalah dan belajar mencarikan/memikirkan sendiri solusinya; menemukan hal-hal yang berguna bagi dirinya; dan bergelut dengan gagasan-gagasan kreatif dan inovatif. Siswa harus mengkonstruksi pengetahuan di benak mereka sendiri, karena guru yang bertugas untuk mentransfer ilmu tidak akan mungkin mampu memberikan semua pengetahuan pada siswa. Dengan dasar tersebut, pembelajaran menurut Ya'cub (2005:178) harus dikemas menjadi proses "mengkonstruksi" pengetahuan dan bukan hanya sekedar "menerima" pengetahuan.

Dalam kaitannya dengan kebutuhan membangun dan meningkatan kesadaran demokrasi, misalnya menyangkut materi ajar "Kemerdekaan berpendapat di muka umum", guru/dosen PKn menjelaskan singkat secara ringkas makna dan arti penting, dasar hukum, hal-hal yang dilarang dan diperbolehkan, serta tata cara pelaksanaan menyampaikan pendapat di muka umum. Uraian ini kemudian dilengkapi dengan beberapa contoh kasus faktual yang mudah diamati siswa/mahasiswa dalam kehidupan keseharian. Selanjutnya para siswa/mahasiswa didorong, dipancing dan dirangsang untuk memikirkan, mengidentifikasi, dan 
membangun sendiri pengetahuannya secara kreatif dalam konteks peningkatan kesadaran kolektifnya.

\section{Inquiry (Menemukan).}

Menemukan (Ya'cub, 2005:78) merupakan bagian inti dari pembelajaran berbasis kontekstual, artinya proses pembelajaran didasarkan pada pencapaian dan penemuan melalui proses berpikir secara sistematis. Sebagai sebuah proses, prinsip inkuiri dalam pembelajaran kontekstual secara umum memiliki siklus sebagai berikut: bertanya (questioning), mengajukan dugaan (hypothesis), pengumpulan data (collecting data), dan penyimpulan (conclusion). Artinya pembelajaran dimulai dengan observasi, kemudian mengajukan pertanyaan, merumuskan hipotes, mengumpulkan data/informasi, hingga berujung pada pengambilan kesimpulan. Siklus kegiatan inkuiri ini tentu saja dilakukan oleh para siswa/mahasiswa dengan materi atau isu dan aspek-aspek teknis metodologisnya dipersiapkan oleh guru. Dengan demikian dalam konteks ini guru dituntut untuk lebih menyiapkan teknik dan proses pembelajaran daripada materi pelajaran itu sendiri, apalagi yang sifatnya materi-materi hafalan.

Dalam konteks peningkatan kesadaran demokrasi, komponen inkuiri ini dapat diimplementasikan misalnya dengan mengambil suatu isu penting dan populer untuk dijadikan materi pembelajaran. Guru/dosen tentu dapat menginisiasi ide kasus, semisal "Unjuk rasa mahasiswa tentang tuntutan pembatalan RUU KUHAP dan UU KPK”. Proses pembelajaran selanjutnya dilakukan bersama-sama dengan para siswa/mahasiswa, guru cukuplah mendampingi dan memfasilitasi secara terbatas. Mengikuti siklus inkuiri, mulamula para siswa ditugaskan melakukan observasi (pengamatan). Observasi ini dilakukan sedemikian rupa oleh para siswa hingga melahirkan berbagai kemungkinan pertanyaan dalam benak mereka: mengapa mahasiswa dan masyarakat melakukan unjuk rasa? apa tuntutan meraka dalam unjuk rasa tersebut? apakah tata cara unjuk yang bertanggng jawab sudah dipenuhi? Apakah njuk rasa itu berjalan damai, tertib dan lancer?, dsb.. Berdasarkan hasil observasi itu para siswa diajak untuk merumuskan jawaban sementara (hipotesa) masingmasing sesuai dengan pertanyaan yang muncul. Tahapan selanjutnya para siswa

Jurnal Edueksos Vol. IX, No. 1, Juni 2020

The journal of social and economics education 
ditugaskan untuk mengumpulkan sebanyak mungkin data/informasi menyangkut isu money politics sesuai dengan pilihan aspeknya. Tahap akhir guru/dosen memfasilitasi para siswa/mahasiswa untuk mengemukakan kesimpulan masingmasing. Kesimpulan inilah penemuan mereka; hasil proses inkuiri para siswa/mahasiswa. Kegiatan ini tentu saja dapat dilakukan secara berkelompok.

\section{Questioning (Bertanya).}

Bertanya merupakan kegiatan yang sangat mendasar bagi guru maupun siswa dalam pembelajaran berbasis kontekstual. Bahkan bertanya merupakan kegiatan utama dari semua aktivitas belajar, karena dengan kegiatan bertanya (Rudiyanto, 2009: 233) guru dapat memotivasi bahkan bisa menilai sejauh mana keberanian dan kemampuan berpikir seorang siswa dalam mengkonstruk pengetahuan dan pemahaman yang ingin didapatkannya.

Kegiatan bertanya merupakan interaksi majemuk (multiple interactions) antara guru/dosen dengan siswa/mahasiswa, siswa/mahasiswa dengan guru/dosen, siswa/mahasiswa dengan siswa/mahasiswa, dan antara siswa/mahasiswa dengan orang berpengetahuan lainnya. Aktivitas-aktivitas tesebut dapat terlihat jelas pada saat diskusi, kegiatan dalam komunitas/masyarakat belajar, bekerja secara berpasangan (work in pairs or in group), dan lain sebagainya. Kesuma dkk (2010: 65) memetakan kegunaan kegiatan questioning dalam proses pembelajaran sbb: 1) menggali informasi, baik yang bersifat administrasi maupun akademis, 2) mengecek tingkat pemahaman siswa, 3) membangkitkan respon siswa, 4) mengukur sejauh mana rasa keingintahuan siswa, 5) mengetahui hal-hal yang belum diketahui siswa, 6) memfokuskan perhatian siswa pada sesuatu yang dikehendaki guru, 7) memberikan stimulus agar siswa bisa memiliki pertanyaanpertanyaan yang kreatif, menarik dan menantang, 8) menyegarkan kembali pengetahuan siswa. Sementara bagi para siswa/mahasiswa kegiatan bertanya (Suryanti dkk, 2008:9) adalah hal penting yang perlu dilakukan dalam pembelajaran berbasis kontekstual, yakni untuk menggali informasi, mengkonfirmasikan apa yang sudah diketahui, dan mengarahkan perhatian pada aspek yang belum diketahuinya. 
Dalam konteks isu-isu kasadaran demokrasi, aspek questioning ini menyangkut konsep-konsep terkait apa itu kemerdekaan menyampaikan pendapat di muka umum, apa bentuk-bentuk menyampaikan pendapat di muka umum sesuai undang-undang nomor 9 tahun 1998, dasar hokumnya apa. Bagaimana tata catanya. Tetapi hal terpenting dalam penerapan komponen bertanya ini adalah bagaimana guru/dosen mampu menstimulus rasa ingin tahu para siswa sehingga mendorong mereka untuk bertanya secara cerdas dan kritis menyangkut berbagai isu penting tentang rendahnya kesadaran demokrasi.

\section{Learning Community (Masyarakat Belajar).}

Pentingnya penerapan konsep Learning Community dalam pembelajaran didasarkan pada gagasan bahwa hasil capaian pembelajaran yang dilakukan secara kelompok akan lebih baik dibandingkan dengan hasil capaian pembelajaran individual. Hasil belajar dalam proses learning community (Suryanti dkk, 2008:9) dapat diperoleh dengan cara sharing antar teman, antar kelompok; yang sudah tahu memberi tahu kepada yang belum tahu, yang pernah memiliki pengalaman membagikan pengalamannya pada orang lain, juga melalui informasi yang didapat di ruang kelas, luar kelas, keluarga, serta masyarakat di demokrasi sekitar yang merupakan bagian dari komponen masyarakat belajar. Dalam konteks materi partisipasi warga Negara dalam pembelaan negara, sebagaiman telah disinggung dalam pembahasan komponen inquiry di atas, penerapan komponen learning community dapat dilakukan untuk membahas dan mendiskusikan semua isu rendahnya kesadaran demokrasi dalam berunjuk rasa yang senantiasa berujung anarkhis dan rusuh sehingga menimbulkan korban dari kedua pihak.

\section{Modelling (Pemodelan).}

Modelling atau pemodelan adalah sebuah pembelajaran keterampilan dengan menyediakan model (contoh) yang bisa diamati dan ditiru oleh setiap siswa/mahasiswa. Dalam kelas pembelajaran kontekstual (Kesuma dkk, 2010:67), kegiatan modelling tidak menjadikan guru sebagai satu satunya model dalam belajar, tetapi dapat juga memanfaatkan siswa yang dianggap memiliki kemampuan untuk memperagakan/mendemonstrasikan sesuatu di depan kelas kepada teman-temannya, seorang ahli yang didatangkan di kelas, media belajar

Jurnal Edueksos Vol. IX, No. 1, Juni 2020

The journal of social and economics education 
dan lain-lain. Menurut Ya'cub (2005:179), belajar dengan cara seperti ini akan membuat hasil pengetahuan yang diperoleh siswa lebih melekat dalam diri siswa, dan mereka akan lebih mudah menerapkannya dalam kehidupan sehari-hari, karena mereka telah melihat dan bisa mengamati suatu contoh/model konkrit dari pengetahuan yang ingi mereka dapatkan.

Menurut Wijaya, A.K (2018) pembelajaran pemodelan dengan bermain peran akan menghasilkan proses peserta didik saling menghargai pendapat kemudian bersama sama mengambil keputusan dalam proses pelaksanaan pemeranan dan pembuatan hasil belajar. Dalam konteks kegiatan bela negara/cinta tanah air, implementasi komponen modelling ini misalnya dilakukan dengan cara guru/dosen mengundang anggota DPRD sebagai model sekaligus menjadi narasumber untuk membedah dan mendiskusikan secara terbuka dan kritis aspekaspek tertentu dari isu-isu rusaknya demokrasi dan rendahnya kesadaran warga masyarakat dikaitkan dengan hak menyampaikan pendapat di muka umum.

\section{Reflection (Refleksi)}

Refleksi pada dasarnya merupakan kegiatan berpikir mengenai apa yang sudah dilakukan; merenungkannya secara jernih, kemudian mengkontekstualisasikannya dengan masa kini untuk kepentingan masa mendatang. Dalam konteks pembelajaran, reflection berarti upaya think back (berpikir ke belakang) tentang apa yang sudah dilakukan di masa lalu, dan berpikir tentang apa yang baru dipelajari dalam sebuah pembelajaran oleh siswa. Dalam hal ini (Ya'cub, 2005:68) siswa mengendapkan apa yang baru dipelajarinya sebagai struktur pengetahuan yang baru, yang merupakan pengayaan atau revisi dari pengetahuan sebelumnya. Menurut Wijaya, A. K. Dkk (2018) pembelajaran PPKn akan memberikan pengalaman reflektif peserta didik menjadi terlatih untuk berpikir kritis, demokratis, dan secara tidak langsung juga mempersiapkan peserta didik agar menjadi warga negara yang baik.

Dalam konteks "hak menyampaikan pendapat di muka umum" terkait peningkatan kesadaran demokrasi, maka kegiatan ini adalah merenungkan dan merasakan apa yang telah dilakukannya dalam pembelajaran menjadi sangat bermakna bagi pribadinya sebagai warga negara.

Jurnal Edueksos Vol. IX, No. 1, Juni 2020

The journal of social and economics education 


\section{Authentic Assessment (Penilaian Sebenarnya).}

Komponen terakhir dalam pembelajaran kontekstual adalah Authentic Assessment, yakni proses pengumpulan berbagai data otentik yang bisa memberikan gambaran pengetahuan perkembangan belajar siswa. Gambaran perkembangan belajar siswa (Kesuma dkk, 2010:69) perlu diketahui oleh guru agar bisa memastikan bahwa siswa mengalami proses pembelajaran dengan benar. Dalam pembelajaran kontekstual assesment idealnya dilakukan sepanjang dan terintegrasi dalam proses pembelajaran, tidak hanya dilakukan pada akhir semester.

\section{KESIMPULAN}

Beberapa kesimpulan sebagai jawaban atas rumusan masalah penelitian yakni: Peningkatan kesadaran demokrasi warga Negara dalam kegiatan menyampaikan pendapat di muka umum melalui pengembangan kesadaran diri ke arah kesadaran moral dan hukum baik individual maupun kolektif; mendorong kesadaran yang bersifat anomous, heterenomous, sosionomouske arah kesadaran autonomous. Upaya peningkatan kesadaran demokrasi ini dilakukan dalam pembelajaran pendidikan kewarganegaraan dengan penerapan pendekatan kontekstual.Ruang lingkup Pendidikan Kewarganegaraan di persekolahan (SD sampai PT) memuat aspek materi tentang penanaman nilai moral yang menuntun peningkatan kesadaran warga Negara tentang demokrasi, politik dan hak-hak warga Negara.Alternatif pendekatan pembelajaran Pendidikan Kewarganegaraan dalam upaya peningkatan kesadaran terhadap pelestarian demokrasi ini adalah Contextual Teaching and Learning, yakni pendekatanpembelajaran yang menghubungkan materi belajar dengan konteks kehidupan nyata.

\section{DAFTAR PUSTAKA}

Al Hakim, S.,dkk., 2012. Pendidikan Kewarganegaraan dalam Konteks Indonesia, Malang : Universitas Negeri Malang.

Azra, A. (2001). "PendidikanKewargaanuntuk demokrasi di Indonesia". Makalah Seminar Nasional II Civic Education di PerguruanTinggi, Mataram, 22-23 April. 
(2007). "Keragaman Indonesia : Pancasila dan Multikulturalisme". Makalah Semiloka Nasional. Yogyakarta, 13 Agustus 2007.

Bakti, Andi Faisal, 2012. Literasi Politik dan Kondolidasi Demokrasi. Jakarta: Churia Press.

Depdiknas. (2006). Pendekatan Kontekstual (Contextual Teaching and Learning). Jakarta: Dikdasmen.

Djahiri, A.K. (1985). Strategi Pengajaran Afektif Nilai Moral VCT dan Games terhadap VCT. Bandung: Jurusan PMPKn FPIPS IKIP Bandung.

Gandal, M. and Finn, Jr.C.E. (1992). Teaching democracy. Freedom Paper USA, (2) $1-28$.

Johnson, E. B., 2011. CTL, Contextual Teaching and Learning: Menjadikan Kegiatan Belajar-Mengajar Mengasyikkan dan Bermakna, Bandung: Kaifa.

Karim, Abdul Gaffar dkk, 2015. "Memahami Tingkat Melek Politik Warga di Kabupaten Sleman”, Laporan Penelitian, Sleman : JPP FISIPOL UGM dan KPU Kabupaten Sleman.

Kesuma, Dharma dkk. 2010. Contextual Teaching and Learning, Garut: Rahayasa Research \& Training.

Komalasari, K. 2010. Pembelajaran Kontekstual, Konsep dan Aplikasi, Bandung: PT Refika Aditama.

Rudiyanto, Mohammad, 2009. "The Implementation of Contextual Teaching and Learning in Englsih Class", dalam Jurnal Okara, Vol.II No.4, November 2009.

Suprijono, A. 2009. Cooperative Learning, Teori \& Aplikasi PAIKEM. Surabaya: Pustaka Pelajar.

Suryanti, dkk., 2008. Model-model Pembelajaran Inovatif, Surabaya: UNESA University Press.

Tilaar, H.A.R. (2002). Pendidikan, Kebudayaan, dan Masyarakat Madani Indonesia. Bandung : PT Remaja Rosdakarya.

Undang-Undang Nomor 9 Tahun 1998 tentang Kemerdekaan Menyampaikan Pendapat di Muka Umum. https://www.solider.id/.

Undang-Undang Nomor 20 tahun 2003 tentang Sistem pendidikan Nasional.

permendiknas nomor 22 tahun 2006 tentang standar isi. https://akhmadsudrajat. files.wordpress.com/2009/04/permendiknas-no-22-tahun-2006.pdf.

Wijaya, Apriyanda Kusuma. (2018). Pengaruh Model Bermain Peran Berbantuan Multimedia Terhadap Keterampilan Kewarganegaraan Peserta Didik. Universitas Pendidikan Indonesia. http://repository.upi.edu/37826/.

Jurnal Edueksos Vol. IX, No. 1, Juni 2020

The journal of social and economics education 
Winataputra, U.S., Budimansyah, D. (2007). Civic Education :konteks, landasan, bahan ajar dan kultur kelas. Bandung : Prodi PKn SPS UPI.

(2008). Multikulturalisme Bhinneka Tunggal Ika dalam Perspektif Pendidikan Kewarganegaraan sebagai Wahana Pembangunan Karakter Bangsa Indonesia. Acta Civicus. 2, (1), 1-16.

(2005). "Pendidikan Kewarganegaraan Untuk Membangun Masyarakat Demokratis Berkeadaban : Tinjauan Filosofis-Pedagogis". Makalah pada Seminar dan Lokakarya Dosen PKn PTN dan PTS, Medan, 22 September.

Wijaya, Apriyanda Kusuma. Rahmat, K. Komalasari (2018). Reflective Experiences of Students to the Integration of Role Playing Model with Multimedia In Citizenship Education. Advances in Social Science, Education and Humanities Research, volume 251. Annual Civic Education Conference (ACEC2018):https://www.atlantis-press.com/proceedings/acec-18/25905987.

Ya'cub, M. 2005. Penerapan CTL dalam Pembelajaran Ilmu Agama dan Umum di Pesantren Hidayatullah Surabaya", dalam Jurnal Nizamia, Vol.8, No.2, Desember 2005. 